\title{
THE KINETICS OF BASE-CATALYZED METHANOLYSIS OF WASTE COOKING OIL
}

Olivera S. Stamenković1, Milan D. Kostić1, Nataša M. Joković ${ }^{\text {, Vlada B. Veljković1 }}$

1Faculty of Technology, University of Niš, Leskovac, Serbia

${ }^{2}$ Faculty of Science and Mathematics, Department of Biology and Ecology, University of Niš, Niš, Serbia

The homogeneous base-catalyzed methanolysis of waste cooking oil (WCO) was investigated at a methanol:WCO molar ratio of 6:1, the initial $\mathrm{KOH}$ amount of $1 \%$ (based on the oil weight) and moderate temperatures $\left(30^{\circ} \mathrm{C}\right.$ to $60{ }^{\circ} \mathrm{C}$ ) with the aim to model the methanolysis reaction kinetics. It was observed that the methanolysis reaction occurred via a pseudo-homogeneous regime where the chemical reaction controls the overall process kinetics and with no mass transfer limitation. It was shown that irreversible pseudo-first and -second order reactions were reliable for describing the methanolysis reaction. However, a better fitting of experimental data was observed by using the irreversible pseudo-second order kinetic model. The reaction rate constant increased with increasing the reaction temperature and at $60{ }^{\circ} \mathrm{C}$ the WCO conversion of $97 \%$ was achieved in 3 minutes. The final products satisfied the EN 14214 biodiesel standard specifications.
(ORIGINAL SCIENTIFIC PAPER)

UDC 665.34.094

662.756 .3

Keywords: biodesel; kinetics; methanolysis; waste cooking oil.

\section{Introduction}

Technological development, global warming and the increase of the environmental pollution have directed scientific research towards alternative and ecologically acceptable energy resources. One of them, biodiesel, which is a mixture of fatty acid alkyl esters (FAAE) derived from different renewable sources rich in triacylglycerols (TAG), has a great significance. The basic feedstocks for industrial biodiesel production are edible vegetable oils but their usage is restricted by their consumption in human nutrition and food industry, as well as by their high cost. In order to overcome these limitations, the researchers and biodiesel manufacturers focus their attention on using low-cost feedstocks such as waste cooking oil (WCO).

WCOs are promising feedstocks for the biodiesel production because of their lower price than that of pure edible vegetable oils, relatively easy availability and possibility for solving their dumping problems and pollution of the water and land resources [1]. An important fact is that the use of $\mathrm{WCO}$ as a feedstock reduces the biodiesel production cost by about $60-70 \%$ [1]. Although there is a lack of information of the worldwide WCO production, Lam et al. [2] have reported that there is enough WCOs to be considered as a significant feedstock for the biodiesel production. The biodiesel production from WCOs depends on their physico-chemical properties and primarily on their content of free fatty acids (FFAs) and water.
In the biodiesel production from WCOs, both catalyzed and non-catalyzed alcoholysis reactions have been employed. The homogeneously-catalyzed reaction is still most often used for the biodiesel production. Basecatalyzed acoholysis is used for biodiesel synthesis from WCO with the lower content of FFA. Acid catalysts are suitatable for the biodiesel production from WCOs with the high FFA content since they simultaneously catalyze esterification and the alcoholysis reaction [3]. Requiring stronger reaction conditions and longer time for completition, acid-catalyzed methanolysis is less important than the base-catalyzed reaction $[4,5]$. Two- step processes for the biodiesel production consisting of acid-catalyzed esterification of FFA in WCO and base-catalyzed methanolysis of the treated oil from the first step are promissing for the biodiesel production from WCOs with the high FFA content. The use of acid catalysts allows the FFA conversion to alkyl esters, thus reducing the FFA content, and the aloholysis of the treated oil over a base catalyst can be performed. A short review of one- and two-step processes for FAAE synthesis from WCOs is given in Table 1.

The knowledge of the alcoholysis reaction kinetics is fundamental for the process development and the reactor design, operation, scale-up, analysis and control. The alcoholysis reaction kinetics is necessary for establishing the mathematical model describing the reaction rate

\footnotetext{
*Author address: Olivera S. Stamenković; Faculty of Technology, University of Niš, Bulevar Oslobođenja 124, 16000 Leskovac, Serbia

E-mail: oliverastam@yahoo.com

The manuscript received: April, 01, 2015.

Paper accepted: April, 23, 2015.
} 
and the product yield. In the studies of homogeneously catalyzed methanolysis two stages are well-recognized. The initial heterogeneous stage is controlled by the mass transfer rate caused by the incomplete miscibility of the reactants, while the second, pseudo-homogeneous stage is chemically controlled.

The kinetics of the methanolysis reaction of various oily feedstocks is described by different kinetic models. Some of them are based on the stepwise reversible alcoholysis reaction $[17,18]$ and include the side saponification reactions [19]. Recently, the models that assume the irreversible overall reaction have been more frueqently used because of their simplicity, no complex computation and good accuracy. The most often used reaction kinetic models are irreversible pseudo-first order [20-26] or -second order [22,23,27-32] and irreversible pseudo- second order followed by reversible second-order [3337].

The present paper deals with the $\mathrm{KOH}$-catalyzed methanolysis of the WCO collected from food cooking in a local household. The reaction was examined at a methanol:WCO molar ratio of $6: 1$, the initial $\mathrm{KOH}$ amount of $1 \%$ (based on the oil weight) and moderate temperatures $\left(30^{\circ} \mathrm{C}\right.$ to $\left.60^{\circ} \mathrm{C}\right)$. The main aim was to model the reaction kinetics using simple irreversible reaction rate laws like pseudo - first and - second order, and to select the more appropriate one with respect of the goodness of fit and accuracy. Furthermore, the obtained ester product was purified and characterized in order to estimate its quality for the use as biodiesel.

Table 1. A review of one-and two-step processes of homogeneous catalyzed WCO alcoholysis

\begin{tabular}{|c|c|c|c|c|c|c|c|c|}
\hline \multirow[t]{2}{*}{ Feedstock } & \multirow{2}{*}{$\begin{array}{l}\text { Type, volume of } \\
\text { reactor, } \mathrm{cm}^{3} / \text { Type } \\
\text { of agitator, agitation } \\
\text { intensity, rpm }\end{array}$} & \multirow[t]{2}{*}{ Alcohol } & \multirow{2}{*}{$\begin{array}{l}\text { Alcohol:oil molar } \\
\text { ratio, } \mathrm{mol} / \mathrm{mol}\end{array}$} & \multirow[t]{3}{*}{ Catalyst/concentration ${ }^{a}$} & \multirow{3}{*}{$\begin{array}{l}\text { Tempera- } \\
\text { ture, }{ }^{\circ} \mathrm{C}\end{array}$} & \multicolumn{2}{|c|}{ Optimal reaction conditions } & \multirow{2}{*}{$\begin{array}{l}\text { Refe- } \\
\text { rence }\end{array}$} \\
\hline & & & & & & Reaction conditions & $\begin{array}{l}\text { Yield } \\
\text { (Conversion), } \\
\% / \text { Time, h }\end{array}$ & \\
\hline \multicolumn{7}{|c|}{ One step processes } & & \\
\hline WCO & $\begin{array}{l}\text { Two-necked Woulf } \\
\text { flask / Magnetic }\end{array}$ & Methanol & $3.6: 1-5.4: 1$ & $\mathrm{NaOH}, 0.2-1 \%$ & 65 & $4.8: 1 ; 0.6 \%$ & $\approx 90 / 1$ & [6] \\
\hline $\begin{array}{l}\text { WCO (olive } \\
\text { and sunflower } \\
\text { oil) }\end{array}$ & $\begin{array}{l}\text { Spherical reactor, } \\
500 / \text { Mechanical }\end{array}$ & Methanol & $3: 1-9: 1$ & $\begin{array}{l}\mathrm{NaOH}, \mathrm{KOH}, \mathrm{CH}_{3} \mathrm{ONa} \text {, } \\
\mathrm{CH}_{3} \mathrm{OK}, 0.1-1.5 \%\end{array}$ & $25-65$ & $6: 1 ; \mathrm{KOH} ; 1 \% ; 65^{\circ} \mathrm{C}$ & $\approx 95 / 2$ & [7] \\
\hline WCO & $\begin{array}{l}\text { Flat bottom two } \\
\text { necks flask, } 500 / \\
\text { Magnetic }\end{array}$ & Methanol & $3: 1-10: 1$ & $\mathrm{KOH}, 0.5-2.0 \%$ & 70 & $6: 1 ; 1 \%$ & $98.2 / 1$ & [8] \\
\hline $\begin{array}{l}\text { WCO } \\
\text { (sunflower oil) }\end{array}$ & $\begin{array}{l}\text { Glass reactor }^{b} / \\
\text { Magnetic, } 1100\end{array}$ & Methanol & $4: 1-6: 1$ & $\mathrm{CH}_{3} \mathrm{ONa}, 0.5-1.5 \%$ & $55-65$ & $6: 1 ; 1 \% ; 60^{\circ} \mathrm{C}$ & $(99) / 0.08$ & [9] \\
\hline $\begin{array}{l}\text { WCO (sun- } \\
\text { flower oil) }\end{array}$ & - & Methanol & $3: 1-9: 1$ & $\begin{array}{l}\mathrm{KOH}, \mathrm{NaOH}, 0.5 \text { and } \\
1.0 \%\end{array}$ & $\begin{array}{l}25 \text { and } \\
65\end{array}$ & $6: 1 ; 1 \% \mathrm{KOH} ; 65^{\circ} \mathrm{C}$ & $96 / 1$ & [10] \\
\hline $\begin{array}{l}\text { WCO (corn, } \\
\text { sunflower and } \\
\text { canola oils) }\end{array}$ & & & & & & & $94.5 / 1$ & \\
\hline WCO & $\begin{array}{l}\text { Three-neck flask, } \\
500 \text { / Mechanical }\end{array}$ & Methanol & $5: 1-12: 1$ & $\mathrm{KOH}, 0.5-1.5 \%$ & $30-70$ & $\begin{array}{l}7: 1-8: 1 ; 0.75 \%, 30- \\
50^{\circ} \mathrm{C}\end{array}$ & $88-90 / 1.3-1.5$ & {$[11]$} \\
\hline WCO & $\begin{array}{l}\text { Stainless-steel } \\
\text { reactor, } 5000 \text { / } \\
\text { Mechanical, 100-600 }\end{array}$ & Methanol & $50: 1-250: 1$ & $\mathrm{H}_{2} \mathrm{SO}_{4}, 1.5-3.5^{\mathrm{c}}$ & $\begin{array}{l}70 \text { and } \\
80\end{array}$ & $\begin{array}{l}400 \mathrm{rpm}: 245: 1 ; 1.5 \\
\mathrm{~mol} \%: 80^{\circ} \mathrm{C}\end{array}$ & $99.4 / 4$ & [4] \\
\hline WCO & $\begin{array}{l}\text { Stainless steel } \\
\text { continuous reactor }\end{array}$ & Methanol & $50: 1$ & $\mathrm{H}_{2} \mathrm{SO}_{4}, 15 \%$ & $80^{d}$ & & $(97) / 4$ & [5] \\
\hline WCO & - & Methanol & $10: 1-24: 1$ & $\mathrm{H}_{2} \mathrm{SO}_{4}, 3-6 \%$ & 95 & $20: 1 ; 4 \%$ & $>90 / 10$ & [12] \\
\hline \multicolumn{9}{|c|}{ Two-step (acid/base catalyzed) processes } \\
\hline \multirow[t]{2}{*}{ WCO } & $\begin{array}{l}\text { Round bottom two } \\
\text { necks flask / }\end{array}$ & Methanol & & $\mathrm{H}_{2} \mathrm{SO}_{4}, 0.5-1.5 \%$ & $45-55$ & $6.1: 1 ; 0.68 \% ; 51^{\circ} \mathrm{C}$ & $-/ 1$ & [13] \\
\hline & Magnetic, 400 & Methanol & $5.2: 1-13: 1$ & $\mathrm{KOH}, 0.5-1.5 \%$ & $50-60$ & $9: 1 ; 1 \% ; 55^{\circ} \mathrm{C}$ & $90.6 / 1$ & \\
\hline \multirow[t]{2}{*}{ WCO } & & Methanol & $30: 1$ & $\mathrm{H}_{2} \mathrm{SO}_{4}, 5 \%$ & 65 & & $-/ 3$ & {$[14]$} \\
\hline & & Methanol & $15: 1-35: 1$ & $\mathrm{KOH}, 0.05-0.15 \%$ & $60-70$ & $25: 1 ; 0.15 \% ; 60^{\circ} \mathrm{C}$ & $93.2 / 1$ & \\
\hline \multirow[t]{2}{*}{ WCO } & Conical flask, 150 / & Methanol & $0.5: 1-0.8: 1$ & $\mathrm{H}_{2} \mathrm{SO}_{4}, 1-3 \%$ & $60-66$ & $0.8: 1 ; 3 \%$ & $(97.6)^{f} / 0.13$ & [15] \\
\hline & & Methanol & $14.2: 1$ & $\mathrm{NaOH}, 0.91 \%$ & & $26-60^{\circ} \mathrm{C}$ & $98.8 / 0.08$ & \\
\hline \multirow[t]{2}{*}{ WCO } & $\begin{array}{l}\text { Microtube reactor, } \\
\text { i.d. } 0.508 \mathrm{~mm} \text { and }\end{array}$ & Methanol & $4.5: 1-18: 1$ & $\mathrm{H}_{2} \mathrm{SO}_{4}, 0.5-2 \%$ & $55-70$ & $\begin{array}{l}\text { Microtube reactor; } 9: 1 \text {; } \\
1 \% ; 65^{\circ} \mathrm{C}\end{array}$ & $(77.5)^{f} / 0.001$ & [16] \\
\hline & $\begin{array}{l}\text { length } 1.2 \mathrm{~m} \text {; Batch } \\
\text { reactor }\end{array}$ & Methanol & $4.5: 1-12: 1$ & $\mathrm{KOH}, 1 \%$ & 65 & $9: 1$ & $91.8 / 0.001$ & \\
\hline
\end{tabular}




\section{Theoretical background}

For the purpose of modeling the kinetics of $\mathrm{KOH}$-catalyzed methanolysis of WCO, the following assumptions are introduced:

a) The methanolysis reaction is shown by the following overall stoichiometric equation:

$A+3 B \stackrel{\text { Catalyst }}{\leftrightarrow} 3 R+S$

where $A$ is TAG, $B$ is methanol, $R$ is fatty acid methyl esters (FAME) and $S$ is glycerol.

It is considered that the overall reaction occurs in one step, although it actualy occurs via three consecutive reversible reactions where TAG stepwise converted in glycerol and FAME. This assumption is proved by too small concentrations of mono- and diacylglycerols (MAGs and DAGs, respectively) because of their much faster consumption rates in comparison to that of TAGs.

b) Because of the agitation intensity of the reaction mixture, the reaction mixture is considered as a pseudo-homogeneous system without the mass transfer limitation, so the overall process kinetics is chemically controlled [38-40]. Also, the reaction mixture is perfectly mixed, ensuring its uniform composition.

c) The methanolysis reaction is an irreversible pseudo-first- or -second order reaction with respect to TAG $[22,23,32]$. Because of the excess of methanol and a low product concentration in the early reaction period, the reverse reactions are negligible.

d) The neutralization reaction of FFAs is ignorable because of their very low content (section 3.1). The saponification reaction is also negligible at the low initial catalyst amount and reaction temperature. Vicente et al. [41] showed that the saponification reactions were insignificant because it accounted for a FAME yield loss of no more than $3 \mathrm{~mol} \%$ when the sunflower oil methanolysis was carried out at $65^{\circ} \mathrm{C}$, using $1 \%$ of $\mathrm{KOH}$ and a 6:1 sunflower oil:methanol molar ratio. We expected the FAME yield loss to be even lower for the reactions carried out at lower temperatures.

According to the assumption (c), the TAG conversion rate can be expressed as irreversible pseudo-first order or -second order kinetic law, respectively:

$\left(-r_{A}\right)=-\frac{d c_{A}}{d t}=k_{1} c_{A}$

and

$\left(-r_{A}\right)=-\frac{d c_{A}}{d t}=k_{2} c_{A}^{2}$.

where $k_{1}$ and $k_{2}$ are reaction rate constants for the irreversible pseudo-first and -second order reaction, respectively, and $C_{A}$ is TAG concentration in the oil phase. Since:

$c_{A}=c_{A 0}\left(1-x_{A}\right)$ where $X_{A}$ is TAG conversion degree, Eqs. (2) and (3) can be transformed into the following expressions, respectively:

$\frac{d x_{A}}{d t}=k_{1} c_{A O}\left(1-x_{A}\right)$

and

$\frac{d x_{A}}{d t}=k_{2} c_{A 0}\left(1-x_{A}\right)^{2}$

where $c_{A 0}$ is the initial TAG concentration. Taking into account the initial reaction condition $\left(t=0, x_{A}=0\right)$, the integration of Eqs. (5) and (6) gives the following equations, respectively:

$-\ln \left(1-x_{A}\right)=k_{1} \cdot t$

and

$\frac{x_{A}}{1-x_{A}}=k_{2} C_{A o} \cdot t$

The reaction rate constants $k_{1}$ and $k_{2}$ can be estimated from the slope of the linear dependence of $-\ln \left(1-x_{A}\right)$ and $\frac{x_{A}}{1-x_{A}}$ on $t$, respectively.

The significance of the model was statistically evaluated based on the mean relative percent deviation (MRPD) and the coefficient of determination $\left(R^{2}\right)$ calculated by Eqs. (9) and (10), respectively:

$M R P D=\frac{100}{n} \sum_{i=1}^{n}\left|\frac{x_{A p i}-x_{A a i}}{x_{A a i}}\right|$

$R^{2}=\frac{\sum_{i=1}^{n}\left(x_{A p, i}-x_{A a, i}\right)^{2}}{\sum_{i=1}^{n}\left(x_{A p, i}-x_{A m}\right)^{2}}$

where $X_{A P}$ and $X_{A a}$ are predicted and experimental values of the TAG conversion degree, respectively, $X_{A m}$ is the mean value of the TAG conversion degree (\%) and $n$ is the number of experimental runs.

\section{Materials and methods}

Materials

The used WCO was collected in a local household from food cooking using the commercial sunflower oil. The oil was used for several times at the cooking temperature of about $150{ }^{\circ} \mathrm{C}$. The oil density and viscosity, determined at $20^{\circ} \mathrm{C}$, were $920 \mathrm{~g} / \mathrm{L}$ and $108 \mathrm{mPa}$ s, respectively. Having the acid value of $0.36 \mathrm{mg} \mathrm{KOH} / \mathrm{g}$, the WCO could be processed by the $\mathrm{KOH}$-catalyzed methanolysis [42]. The iodine and saponification values of the oil were $128 \mathrm{~g} \mathrm{I}_{2} / 100 \mathrm{~g}$ and $184 \mathrm{mg} \mathrm{KOH} / \mathrm{g}$, respectively. The water content of the WCO, measured by the cou- 
lometric Karl Fischer volumetric titration was 380 ppm $(0.38 \%)$, which was slightly above the limited value of $0.3 \%$ [42]. The fatty acid composition of the WCO was determined by GC and GC-MS analysis [43]. The WCO consisted of palmitic $(7.25 \%)$, stearic $(3.47 \%)$, arachidic $(0.15 \%)$, oleic $(29.36 \%)$, linoleic $(59.43 \%)$ and linolenic $(0.14 \%)$ acid. Methanol $(99.5 \%)$ and $\mathrm{KOH}$ (pellets; $85 \%)$ were from Zorka-Pharma (Serbia) and Lach-Ner (Czech Republic), respectively. $\mathrm{HCl}(36 \%)$ and anhidrous $\mathrm{Na}_{2} \mathrm{SO}_{4}$ were purchased from Centrohem (Serbia) and Sigma Aldrich (USA). HPLC grade methanol and $n$-hexane were obtained from Promochem LGC (Germany), while isopropanol was from Carlo Erba (Italy). HPLC standards for methyl esters and glycerides were obtained from Sigma Aldrich (USA).

\section{Equipment, reaction conditions and procedure}

The experiments were performed in a three-neck glass flask $(250 \mathrm{~mL})$ equipped with a condenser and a magnetic stirrer. The agitation intensity was kept constant at $600 \mathrm{rpm}$ in all experiments by using a voltage regulator. The reactor was immersed in a glass chamber filled with water circulating from a thermostated bath in order to maintain the reaction temperature at desired levels. The methanolysis reaction of the WCO was carried out at temperatures 30,45 or $60^{\circ} \mathrm{C}$, the $6: 1$ methanol:WCO molar ratio and the $\mathrm{KOH}$ amount of $1 \%$ (based on the oil weight) under atmospheric pressure.

Methanol $(10.14 \mathrm{~g})$ and $\mathrm{KOH}(0.4596 \mathrm{~g})$ were agitated in the reactor at the desired temperature until the all catalyst amount was dissolved in methanol. The WCO $(45.96 \mathrm{~g})$ was thermostated separately and added to the reactor. As soon as the magnetic stirrer was turned on, the reaction was timed. During the reaction, the samples $(1 \mathrm{~mL})$ were removed from the reaction mixture, immediately quenched by adding a required amount of the aqueous $\mathrm{HCl}$ solution $(11 \%$ vol.) to neutralize the $\mathrm{KOH}$ and then centrifuged ( $3500 \mathrm{rpm}$ for $15 \mathrm{~min}$ ). The upper layer was withdrawn, dissolved in the isopropanol $/ n$-hexane $(5: 4$ $\mathrm{v} / \mathrm{v}$ ) mixture in a ratio 1:200 and filtered through a 0.45 $\mu \mathrm{m}$ Millipore filter. The obtained filtrate was utilized for the HPLC analysis that gave contents of FAMEs, TAGs, DAGs and MAGs in the ester/oil phase [33]. The conversion degree of TAGs during the reaction was calculated from the initial and actual (TAG and TAG, respectively) content of TAGs (\%) in the FAME/oil fraction as follows:

$$
x_{A}=1-T A G / T A G_{0}
$$

\section{FAME purification and characterization}

After the reaction completition, the reaction mixture was poured into a separating funnel and left to separate in two (esters and alcohols) layers. The remained catalyst in the upper ester layer was carefully neutralized by adding the $\mathrm{HCl}$ solution (1 mol/L), which was gravitationaly separate. Then, distilled water and the ester phase were mixed in the volume ratio of 1:5 in the separating funnel. After shaking, the two-phase mixture was left to separate to the ester layer and the water phase. At the end, the washed ester phase was dried using anhydrous $\mathrm{Na}_{2} \mathrm{SO}_{4}$ that was removed by filtration. The final ester product was characterized according to the biodiesel standard methods.

\section{Results and discussion}

\section{Analysis of methanolysis reactions}

The change of the reaction mixture composition with time at $30^{\circ} \mathrm{C}$ is shown in Figure 1. Generally, two reaction periods could be observed: the initial period during which the reaction was very fast, indicating no liquidliquid mass transfer limitation, followed by the second period, longer than the first one, where the composition evolved slowly towards the reaction completition. Simultaneously, with the increase of the FAME content during the reaction, the TAG content decreased. The shapes of curves are typical for homogeneous base-catalyzed methanolysis of vegetable oils in the absence of mass transfer limitation in the initial reaction period. Depending on the reaction temperature, the FAME content of above $98 \%$ was achieved at all three reaction temperatures, but for different reaction times. In the present study, the high FAME formation was obtained in a much shorter reaction time compared to the conversion degrees for WCO in the previous studies (Table 1). The MAG and DAG concentrations slowly increased in the initial reaction period, then decreased and stayed nearly constant at negligible levels up to the end of the reaction. These very low concentrations verified the assumption (a). At higher reaction temperatures $\left(45^{\circ} \mathrm{C}\right.$ and $60^{\circ} \mathrm{C}$ ), the same type of variations of TAG, MAG, DAG and FAME concentrations were observed, provided that the FAME formation was much faster than that at $30^{\circ} \mathrm{C}$. The positive influence of the reaction temperature on the reaction rate was observed in the previous investigations of WCO methanolysis $[7,9,10]$.

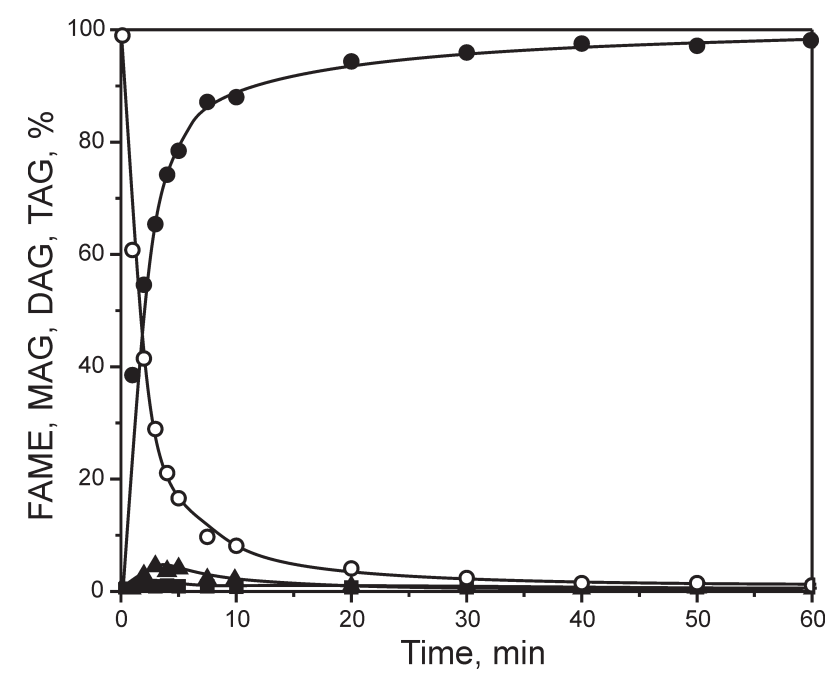

Figure 1. Variations of the reaction mixture composition with the progress of the methanolysis reaction at $30^{\circ} \mathrm{C}$ (FAME - •; MAG - $\mathbf{\Delta}$; DAG - - ; TAG - ०) 

tion

Modeling the kinetics of the WCO methanolysis reac-

The kinetic of the WCO methanolysis reaction was described by the irreversible pseudo-first and -second order reaction rate law with respect to TAG. In Figure 2 , the dependences of $-\ln \left(1-x_{A}\right)$ and $x_{A} /\left(1-x_{A}\right)$ on time are shown. The observed linear dependences confirm Eqs. (7) and (8). The reaction rate constants $k_{1}$ and $k_{2}$ were calculated from the slope of the corresponding linear curves, and their values are given in Table 2 along with the coefficient of determination $\left(R^{2}\right)$. As expected, the reaction rate constants increased with increasing the reaction temperature.
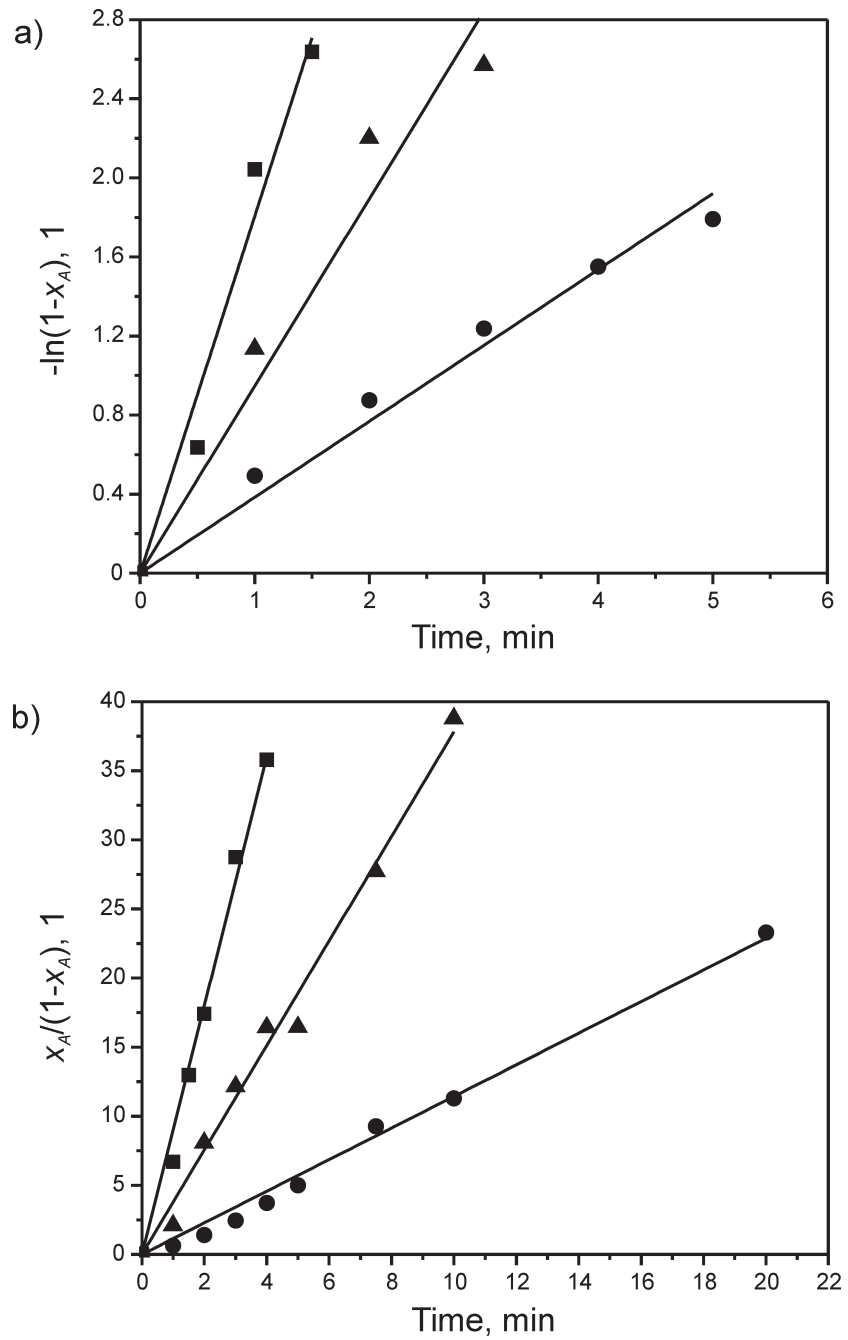

Figure 2. The irreversible pseudo-first (a) and irreversible pseudo-second order $(b)$ reaction models of methanolysis at various reaction temperatures $\left(\bullet-30^{\circ} \mathrm{C}, \boldsymbol{\Delta}-45^{\circ} \mathrm{C}\right.$ and $\left.\boldsymbol{-}-60^{\circ} \mathrm{C}\right)$

The high values of $R^{2}$ confirmed the acceptability of both proposed kinetic models for describing the kinetic of the $\mathrm{KOH}$-catalyzed WCO methanolysis. Slightly higher $R^{2}$ values were observed for the irreversible pseudosecond order reaction, thus indicating that it was more adequate for modeling the kinetics of WCO methanolysis. The accuracy of the applied kinetic models were also compared based on the MRPD (\%) between corresponding predicted and actual values of TAG conversion degree. The value of MRPD for irreversible pseudo-first and -second order kinetic models were $\pm 2.53 \%$ and of $\pm 1.45 \%$ (for 32 data), respectively. Based on the $R^{2}$ and $M R P D$ values, the irreversible pseudo-second order was accepted as more adequate for describing the kinetics of the base-catalyzed WCO methanolysis.

Table 2. Rate constants for the irreversible pseudo-first and -second order reaction

\begin{tabular}{ccccc}
\hline & \multicolumn{2}{c}{$\begin{array}{c}\text { Irreversible pseudo-first } \\
\text { order }\end{array}$} & \multicolumn{2}{c}{$\begin{array}{c}\text { Irreversible pseudo- } \\
\text { second order }\end{array}$} \\
\cline { 2 - 5 }$T\left({ }^{\circ} \mathrm{C}\right)$ & $R^{2}$ & $\begin{array}{c}k_{2}, \\
\mathrm{dm}^{3} /(\mathrm{mol} \cdot \mathrm{min})\end{array}$ & $R^{2}$ \\
\hline 30 & 0.384 & 0.979 & 1.381 & 0.991 \\
45 & 0.949 & 0.949 & 4.625 & 0.989 \\
60 & 1.805 & 0.970 & 11.16 & 0.990 \\
\hline
\end{tabular}

The irreversible pseudo-second order kinetic model was the most appropriate for modeling the methanolysis reaction of $O$. acanthium $L$. oil [32] and sunflower oil after the initial mass transfer limitation [36]. The kinetics of base-catalyzed palm and sunflower oil ethanolysis $[31,35]$ was also described by pseudo-second order reaction. Georgogianni et al. $[22,23]$ found out that both irreversible pseudo-first and -second order reactions were reliable for modeling the base-catalyzed conventional (under mechanical stirring and ultrasonication) and in situ methanolysis of cottonseed and sunflower oil. However, due to higher $R^{2}$ value obtained for the first order reaction, they stated that the reaction was rather pseudo-first than second order.

For determining the activation energies for the $\mathrm{KOH}$ catalyzed methanolysis of $\mathrm{WCO}$, the Arrhenius equation was applied:

$k=A \cdot \exp \left(-E_{a} / R T\right)$

where $A$ is the pre-exponential factor, $E a$ is the activation energy, and $R$ is the gas constant. The values of the activation energy, calculated from the slope of the linear dependence of Ink vs 1/T (Figure 3), were $43.4 \mathrm{~kJ} / \mathrm{mol}$ and $58.5 \mathrm{~kJ} / \mathrm{mol}$ for irreversible psedo-first and -second order reactions. Generally, these values are within the range of the activation energy for methanolysis of different oily feedstock $[21,29,32,36,44]$.

Simulation of methanolysis process

The values of the TAG conversion degree for the irreversible psedo-first and-second order reactions were calculated by Eqs. (13) and (14), respectively:

$x_{A}=1-e^{-k_{1} t}$

$x_{A}=\frac{k_{2} C_{A 0} t}{1+k_{2} C_{A 0} t}$ 
a)

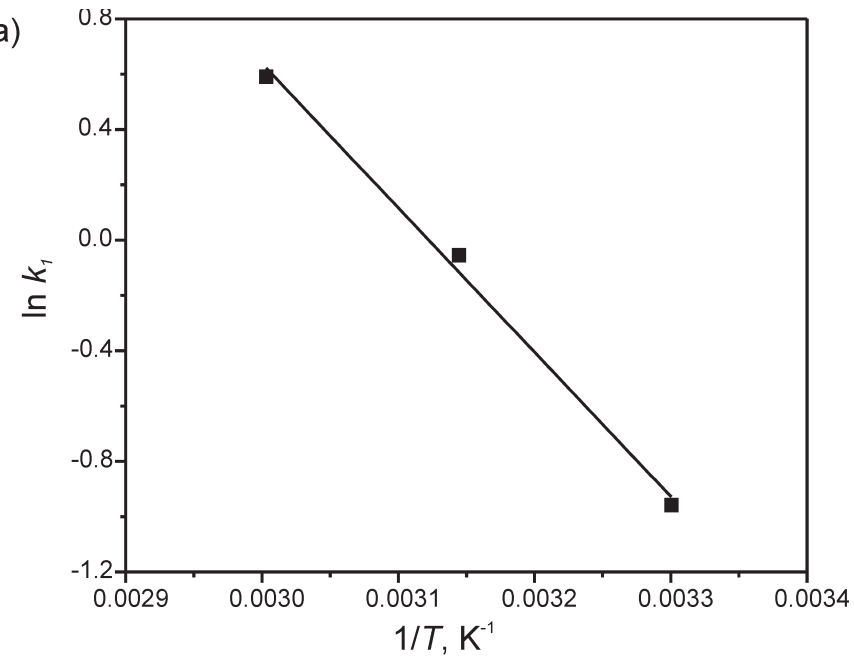

b)

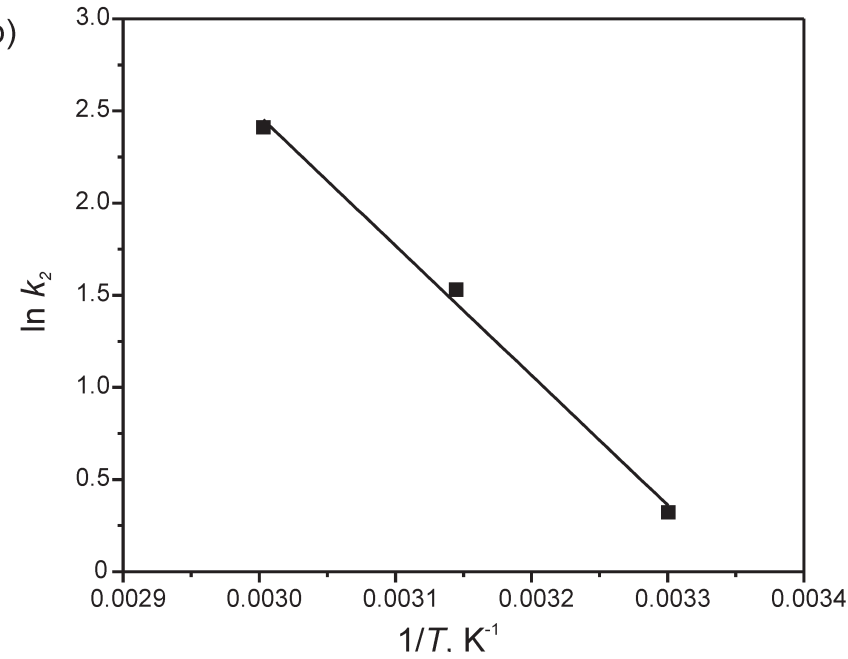

Figure 3. Arrhenius plot of reaction rate constants of TAG methanolysis versus reciprocal of temperature for irreversible pseudo-first (a) and irreversible pseudo-second order (b) reaction models

The comparison of the kinetic model and the experimental data is shown in Figure 4, where the variations of the TAG conversion degree with time are shown. The $M R P D$ between the actual and predicted values of the TAG conversion degree at the temperatures of $30^{\circ} \mathrm{C}, 45^{\circ} \mathrm{C}$ and $60{ }^{\circ} \mathrm{C}$ were $\pm 3.3 \%, \pm 2.4 \%$ and $\pm 1.8 \%$, respectively for the irreversible pseudo-first order kinetic model and $\pm 3.2 \%, \pm 0.36 \%$ and $\pm 0.48 \%$, respectively for the irreversible pseudo-second order kinetic model. Lower values of MRPD observed for the latter model confirmed its slightly better accuracy in fitting the experimental data than the former model. a)

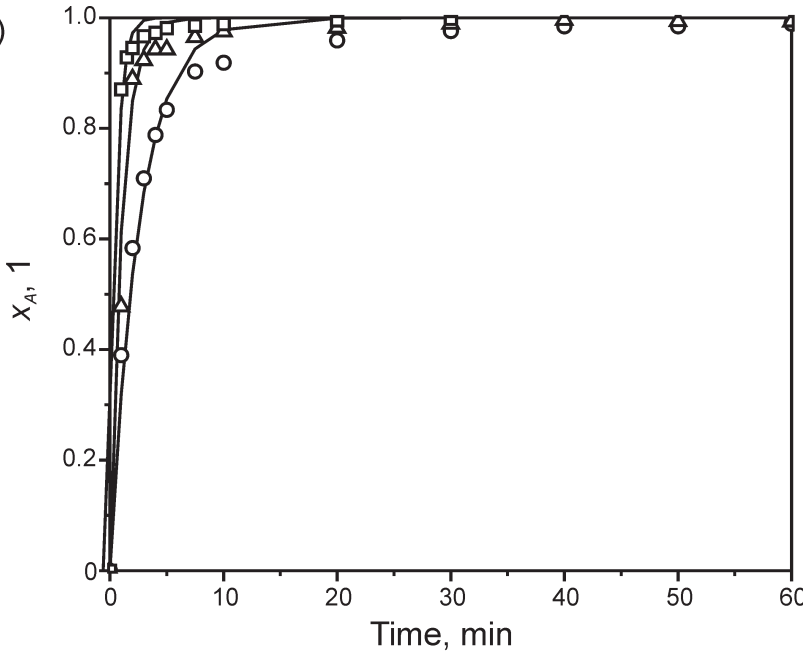

b)

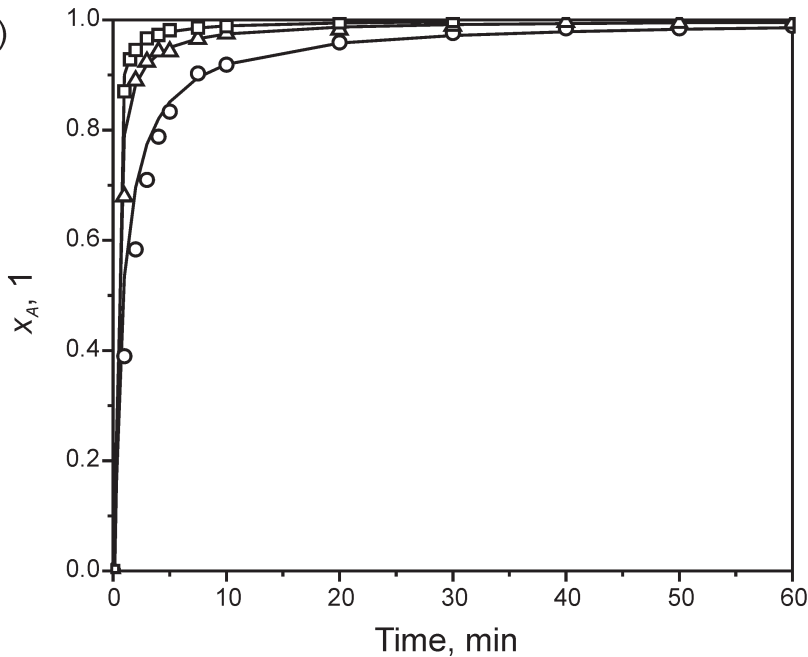

Figure 4. The comparison of the irreversible pseudo-first (a) and irreversible pseudo-second order (b) kinetic models (line) and the experimental data (symbols) during methanolysis at reaction temperatures: $\circ-30^{\circ} \mathrm{C}, \Delta-45^{\circ} \mathrm{C}$ and $\square-60^{\circ} \mathrm{C}$

\section{Biodiesel properties}

The characteristics of the final FAME product obtained by the WCO methanolysis are given in Table 3. For comparison, the characteristics of the esters obtained in the previously reported studies of the homogeneous basecatalyzed alcoholysis of WCO, as well as the specification of the biodiesel standard quality, are also presented in Table 3. The physico-chemical characteristics of the biodiesel from WCO generally satisfied the EN 14214 standard specifications. The exception was the iodine value, which was higher than the maximum value allowed by the European biodiesel standard EN14214. On the other side, the USAASTM D6751 standard does not specify its value. Based on the new consideration, the limitation of the iodine value does not seem to be necessary [45]. 
Table 3. Properties of biodiesel produced from homogeneous base-catalyzed alcoholysis of WCO

\begin{tabular}{|c|c|c|c|c|c|c|}
\hline Catalyst/Alcohol & $\begin{array}{l}\mathrm{KOH} / \\
\text { Methanol }\end{array}$ & $\begin{array}{l}\mathrm{KOH} / \\
\text { Methanol }\end{array}$ & $\begin{array}{l}\mathrm{KOH} / \\
\text { Methanol }\end{array}$ & $\begin{array}{l}\mathrm{NaOCH}_{3} / \\
\text { Ethanol }\end{array}$ & $\begin{array}{l}\mathrm{NaOH} / \\
\text { Ethanol }\end{array}$ & EN14214 \\
\hline \multicolumn{7}{|l|}{ Property, unit } \\
\hline FAME content, $\%$ & 98.8 & 98.2 & 90 & 97.7 & & 96.5 \\
\hline Density at $15^{\circ} \mathrm{C}, \mathrm{kg} / \mathrm{m}^{3}$ & $875^{a}$ & 844 & 880 & $888.3^{b}$ & 870 & $860 / 900$ \\
\hline Viscosity at $40{ }^{\circ} \mathrm{C}, \mathrm{mm}^{2} / \mathrm{s}$ & 2.49 & 4.7 & 4.89 & 2.35 & 5.03 & $3.50 / 5.00$ \\
\hline Flash point, ${ }^{\circ} \mathrm{C}$ & & 159 & 120 & 185 & 164 & $101 \mathrm{~min}$ \\
\hline Sulfur content, mg/kg & & & & & 2 & $10 \max$ \\
\hline Water content, $\mathrm{mg} / \mathrm{kg}$ & 415 & & trace & 300 & 0.0 & $500 \max$ \\
\hline Acid value, $\mathrm{mg} \mathrm{KOH} / \mathrm{g}$ & 0.37 & & 0.43 & 0.48 & 0.29 & $0.5 \max$ \\
\hline lodine value, $\mathrm{g} \mathrm{I}_{2} / 100 \mathrm{~g}$ & 131 & & & & & $120 \max$ \\
\hline Monoglyceride content, \% & 0.70 & & & 2.34 & 0.29 & $0.8 \max$ \\
\hline Diglyceride content, \% & 0.17 & & & 0.0 & 0.19 & $0.2 \max$ \\
\hline Triglyceride content, \% & 0.10 & & & 0.0 & 0.06 & $0.2 \max$ \\
\hline Free glycerol, $\%$ & & & & & 0.022 & $0.02 \max$ \\
\hline Total glycerol, \% & & & & & 0.57 & $0.25 \max$ \\
\hline $\begin{array}{l}\text { Group I metals }(\mathrm{Na}+\mathrm{K}) \text {, } \\
\mathrm{mg} / \mathrm{kg}\end{array}$ & 0.2 & & & & 66 & $5.0 \max$ \\
\hline $\begin{array}{l}\text { Group II metals }(\mathrm{Ca}+\mathrm{Mg}) \\
\mathrm{mg} / \mathrm{kg}\end{array}$ & & & & & 1 & $5.0 \max$ \\
\hline Phosphorus content, $\mathrm{mg} / \mathrm{kg}$ & & & & & 2 & $4.0 \max$ \\
\hline Cloud point, ${ }^{\circ} \mathrm{C}$ & & -2 & 3 & -3 & -1 & Not specified \\
\hline Pour point, ${ }^{\circ} \mathrm{C}$ & & -5 & 0 & -19 & -16 & Not specified \\
\hline Reference & This work & {$[8]$} & [11] & [9] & {$[46]$} & \\
\hline
\end{tabular}

\section{Conclusion}

The $\mathrm{KOH}$-catalyzed methanolysis of WCO was studied at moderate reaction temperatures. The methanolysis reaction was shown to be only chemically controlled. Based on the lower MRPD values between the experimental and calculated values of the TAG conversion degree and higher $R^{2}$ values, the irreversible pseudosecond order reaction rate was chosen for modeling the reaction kinetics. A higher conversion degree (97\%) within a shorter reaction time (3 $\mathrm{min})$ was obtained at the highest reaction temperature of $60{ }^{\circ} \mathrm{C}$. The activation energy of the WCO methanolysis reaction was in the range of the values reported for methanolysis of different oily feedstock. The final products satisfied the EN 14214 biodiesel standard specifications.

\section{Acknowledgment}

This work has been funded by the Ministry of Education, Science and Technological Development of the Republic of Serbia (Project III 45001).

\section{References}

[1] M. C. Math, S. P. Kumar, S. V. Chetty, Technologies for biodiesel production from used cooking oil - A review, Energy for Sustainable Development ,14 (2010) 339-345.
[2] M. K. Lam, M. K. Lee, A. R. Mohamed, Homogeneous, heterogeneous and enzymatic catalysis for transesterification of high free fatty acid oil (waste cooking oil) to biodiesel: A review, Biotechnology Advances 28 (2010) 500-518.

[3] E. Lotero, Y. Liu, D. E. Lopez, K. Suwannakarn, D. A. Bruce, J. G. Goodwin, Synthesis of biodiesel via acid catalysis, Industrial and Engineering Chemistry Research, 44 (2005) 5353-5363.

[4] S. Zheng, M. Kates, M. A. Dubé, D. D. McLean, Acidcatalyzed production of biodiesel from waste frying oil, Biomass and Bioenergy. 30 (2006) 267-272.

[5] Y. Zhang, M. A. Dube, D. D. McLean, M. Kates, Biodiesel production from waste cooking oil: 1. Process design and technological assessment, Bioresource Technology, 89 (2003) 1-16.

[6] P. Felizardo, M. J. Correia, I. Raposo, J. F. Mendes, R. Berkemeier, J. M. Bordado, Production of biodiesel from waste frying oils, Waste Management, 26 (2006) 487-494.

[7] J. M. Encinar, J. F. Gonzalez, A. Rodriguez-Reinares, Biodiesel from used frying oil. Variables affecting the yields and characteristics of the biodiesel, Industrial and Engineering Chemistry Research, 44 (2005) 5491-5499.

[8] M. Agarwal, G. Chauhan, S. P. Chaurasia, K. Singh Study of catalytic behavior of $\mathrm{KOH}$ as homogeneous and heterogeneous catalyst for biodiesel production, Journal of the Taiwan Institute of Chemical Engineers, 43 (2012) 89-94.

[9] N.Azcan, O. Yilmaz, Microwave assisted transesterification of waste frying oil and concentrate methyl ester content of biodiesel by molecular distillation, Fuel, 104 (2013) 
$614-619$

[10] A. A. Refaat, N. K. Attia, H. A. Sibak, S. T. El Sheltawy, G. I. El Diwani, Production optimization and quality assessment of biodiesel from waste vegetable oil, International Journal of Environmental Science and Technology, 5 (2008) 7582.

[11] A. N. Phan, T. M. Phan, Biodiesel production from waste cooking oils, Fuel, 87 (2008) 3490-3496.

[12] Y. Wang, S. Y. Ou, P. Z. Liu, F. Xue, S. Tang, Comparison of two different processes to synthesize biodiesel by waste cooking oil, Journal of Molecular Catalysis A: Chemical, 252 (2006) 107-112.

[13] M. Charoenchaitrakool, J. Thienmethangkoon, Statistical optimization for biodiesel production from waste frying oil through two-step catalyzed process, Fuel Processing Technology, 92 (2011) 112-118.

[14] J. Li, H. Zhou, Y. Cao, Transesterification of waste cooking oil to produce biodiesel using acid and alkaline catalyst, Advanced Materials Research, 518-523 (2012) 35663572.

[15] S. Liu, T. McDonald, Y. Wang, Producing biodiesel from high free fatty acids waste cooking oil assisted by radio frequency heating, Fuel, 89 (2010) 2735-2740.

[16] Y. Tanawannapong, A. Kaewchada, A. Jaree, Biodiesel production from waste cooking oil in a microtube reactor, Journal of Industrial and Engineering Chemistry, 19 (2013) 37-41.

[17] S.K. Karmee, A. Chadha, Preparation of biodiesel from crude oil of Pongamia pinnata, Bioresource Technology, 96 (2005) 1425-1429.

[18] E. Bikou, A. Louloudi, N. Papayannakos, The effect of water on the transesterification kinetics of cotton seed oil with ethanol, Chemical Engineering and Technology, 22 (1999) 70-75.

[19] H. J. Berchmans, K. Morishita, T. Takarada, Kinetic study of hydroxide-catalyzed methanolysis of Jatropha curcas waste food oil mixture for biodiesel production, Fuel, 104 (2013) 46-52.

[20] N.L. da Silva, C.B. Batistella, R.M. Filho, M.R.W. Maciel, Biodiesel production from castor oil: Optimization of alkaline ethanolysis, Energy and Fuels, 23 (2009) 56365642.

[21] A. Bokhari, S. Yusup, R. N. M. Kamil, J. Ahmad, Blending study of palm oil methyl esters with rubber seed oil methyl esters to improve biodiesel blending properties, Chemical Engineering Transactions, 37 (2014) 571-576.

[22] K. G. Georgogianni, M. G. Kontominas, P. J. Pomonis, D. Avlonitis, V. Gergis, Alkaline conventional and in situ transesterification of cottonseed oil for the production of biodiesel, Energy and Fuels, 22 (2008) 2110-2115.

[23] K. G. Georgogianni, M. G. Kontominas, P. J. Pomonis, D. Avlonitis, V. Gergis, Conventional and in situ transesterification of sunflower seed oil for the production of biodiesel, Fuel Processing Technology, 89 (2008) 503509.

[24] C. A. Z Jamil, A. Muslim, Performance of $\mathrm{KOH}$ as a catalyst for transesterification of Jatropha curcas oil, International Journal of Engineering Research and Applications, 2 (2012) 635-639.

[25] R. A. Rabu, I. Janajreh, D. Honnery, Transesterification of waste cooking oil: Process optimization and conversion rate evaluation, Energy Conversion and Management, 65 (2013) 764-769.

[26] B. B. Uzun, M. Kılıç, N. Özbay, A. E. Pütün, E. Pütün,
Biodiesel production from waste frying oils: Optimization of reaction parameters and determination of fuel properties, Energy, 44 (2012) 347-351.

[27] D. Darnoko, M. Cheryan, Kinetics of palm oil transesterification in a batch reactor, Journal of the American Oil Chemists' Society, 77 (2000) 1263-1267.

[28] J.M. Dias, M. C. M. Alvim-Ferraz, M. F. Almeida, Mixtures of vegetable oils and animal fat for biodiesel production: influence on product composition and quality, Energy and Fuels, 22 (2008) 3889-3893.

[29] L. T. T. Huong, P. M. Tan, T. T. V. Hoa, S. Lee, Kinetics of the $\mathrm{KOH}$ catalyzed-methanolysis for biodiesel production from fat of tra catfish, Journal of the Korean Oil Chemists' Society, 25 (2008) 418-428.

[30] H. Lu, Y. Liu, H. Zhou, Y. Yang, M. Chen, B. Liang, Production of biodiesel from Jatropha curcas L. oil Computers and Chemical Engineering, 33 (2009) 10911096.

[31] S. Shahla, G. C. Ngoh, R. Yusoff, The evaluation of various kinetic models for base-catalyzed ethanolysis of palm oil, Bioresource Technology, 104 (2012) 1-5.

[32] M. D. Kostić, N. M. Joković, O. S. Stamenković, V. B. Veljković, Dobijanje biodizela iz ulja semena magarećeg trna (Onopordum acanthium L.), Savremene tehnologije, 3(2) (2014) 35-45.

[33] J. M. Avramović, O. S. Stamenković, Z. B. Todorović, M. L. Lazić, V. B. Veljković, Empirical modeling the ultrasoundassisted base-catalyzed sunflower oil methanolysis kinetics, Chemical Industry and Chemical Engineering Quarterly, 18 (1) (2012) 115-127.

[34] W. M. Clark, N. J. Medeiros, D. J. Boyd, J. R. Snell, Biodiesel transesterification kinetics monitored by $\mathrm{pH}$ measurement, Bioresource Technology, 136 (2013) 771 774.

[35] A. V. Marjanović, O. S. Stamenković, Z. B. Todorović, M. L. Lazić, V. B. Veljković, Kinetics of the base-catalyzed sunflower oil ethanolysis, Fuel, 89 (2010) 665-671.

[36] O. S. Stamenković, Z. B. Todorović, M. L. Lazić, V. B. Veljković, D. U. Skala, Kinetics of sunflower oil methanolysis at low temperatures, Bioresource Technology, 99 (2008) 1131-1140.

[37] P. Sungwornpatansakul, J. Hiroi, Y. Nigahara, T.K. Jayasinghe, K. Yoshikawa, Enhancement of biodiesel production reaction employing the static mixing, Fuel Processing Technology, 116 (2013) 1-8.

[38] H. Noureddini, D. Zhu, Kinetics of transesterification of soybean oil, Journal of the American Oil Chemists' Society, 74 (1997) 1457-1463.

[39] G. Vicente, M. Martinez, J. Aracil, A. Esteban, Kinetics of sunflower oil methanolysis, Industrial and Engineering Chemistry Research, 44 (2005) 5447-5454.

[40] G. Vicente, M. Martinez, J. Aracil, Kinetics of Brassica carinata oil methanolysis, Energy and Fuels, 20 (2006) $1722-1726$.

[41] G. Vicente, M. Martinez, J. Aracil. Integrated biodiesel production: a comparison of different homogeneous catalysts systems. Bioresource Technology, 92 (2004) 297-305.

[42] B. Freedman, E. H. Pryde, T. L. Mounts, Variables affecting the yields of fatty esters from transesterified vegetable oils, Journal of the American Oil Chemists' Society, 61(10) (1984) 1638-1643.

[43] N. Radulović, M. Denić, Z. Stojanović-Radić, D.Skropeta, Fatty and volatile oils of the gypsywort Lycopus europaeus 
L. and the gaussian-like distribution of its wax alkanes, Journal of the American Oil Chemists' Society, 89 (2012) 2165-2185.

[44] I. J. Stojković, I. B. Banković-llić, A. V. Veličković, J. M. Avramović, O. S. Stamenković, D. S. Povrenović, V. B. Veljković, Waste lard methanolysis catalyzed by potassium hydroxide at moderate temperatures, Submitted for publication.

[45] O. Costenoble, M. Mittelbach, S. Schober, J. Fischer, J. Haupt, Improvements needed for the biodiesel standard EN 14214. EC project TREN/D2/44-LOT 1/S07.54676,
NEN, University of Graz and AGQM. 2008, http:// ec.europa.eu/energy/renewables/biofuels/doc/standard/ lot1.pdf (March, 2015)

[46] A. B. Chhetri, K. C. Watts, M. R. Islam, Waste cooking oil as an alternate feedstock for biodiesel production, Energies 1 (2008) 3-18.

\section{Izvod}

\section{KINETIKA BAZNO KATALIZOVANE METANOLIZE OTPADNOG KORIŠĆENOG ULJA}

Olivera S. Stamenković1, Milan D. Kostić ${ }^{\text {, Nataša M. Joković }}{ }^{2}$, Vlada B. Veljković

1Tehnološki fakultet, Univerzitet u Nišu, Leskovac, Srbija
2Prirodno-matematički fakultet, Departman za biologiju i ekologiju, Univerzitet u Nišu, Niš, Srbija

Otpadno korišćeno ulje je ispitivano kao sirovina za dobijanje biodizela postupkom homogene bazno-katalizovane metanolize pri umerenim reakcionim uslovima: molski odnos metanol:ulje 6:1, količina $\mathrm{KOH}$ kao katalizatora $1 \%$ (računato na masu ulja) i na temperaturama od $30^{\circ} \mathrm{C}$ do $60^{\circ} \mathrm{C}$, sa ciljem modelovanja kinetike reakcije. Zapaženo je da ne postoje maseno-prenosna ograničenja brzine procesa u njegovom početnom periodu i da se reakcija metanolize odigrava u pseudo-homogenom režimu, u kome hemijska reakcija odredjuje ukupnu brzinu procesa. Kinetika reakcije metanolize otpadnog korišćenog ulja je modelovana primenom nepovratne reakcije pseudo-prvog i pseudo-drugog reda. lako su oba modela bila pouzdana za opisivanje kinetike reakcije, bolje slaganje eksperimentalnih i izračunatih vrednosti stepena konverzije ulja je dobijeno u slučaju primene modela nepovratne reakcije pseudo-drugog reda. Konstante brzine reakcije se povećavaju sa povišenjem temperature. Konverzija ulja od $97 \%$ je ostvarena za 3 minuta trajanja reakcije na temperaturi $60{ }^{\circ} \mathrm{C}$. Karakteristike dobijenog biodizela su u okviru vrednosti propisanih standardom kvaliteta bodizela EN14214.
(ORIGINALNI NAUČNI RAD)

UDK 665.34.094

662.756 .3

Ključne riječi: biodizel; kinetika; metanoliza; otpadno korišćeno ulje 